STUDIA I PRACE WYDZIAŁU NAUK EKONOMICZNYCH I ZARZĄDZANIA NR 40

DOI: $10.18276 / \operatorname{sip} .2015 .40 / 2-16$

\author{
Arkadiusz Babczuk ${ }^{*}$ \\ Marian Kachniarz* \\ Uniwersytet Ekonomiczny we Wrocławiu
}

\title{
POLSKIE PARKI NARODOWE - UJĘCIE INSTYTUCJONALNE
}

\section{STRESZCZENIE}

Walory przyrodnicze i kulturowe polskich parków narodowych powinny być objęte odpowiednimi formami zarządzania. Celem artykułu jest charakterystyka formalnych i nieformalnych ram funkcjonowania parków narodowych w Polsce oraz sformułowanie rekomendacji zmian w tym zakresie. Przekształcenie parków z jednostek budżetowych w państwowe podmioty prawne dało im większą samodzielność organizacyjną. $Z$ jednej strony zwiększa to motywacje i odpowiedzialność dyrektorów, z drugiej - grozi dryftem z pozycji podmiotów chroniących przyrodę w kierunku podmiotów gospodarujących jej zasobami, z funkcji ochronnych do funkcji zdobywania przychodów. Taka pokusa rodzi się zwłaszcza w warunkach braku jasno określonych reguł oraz ograniczonego finansowania budżetowego.

Słowa kluczowe: parki narodowe, państwowe osoby prawne, instytucje nieformalne

\section{Wprowadzenie}

Park narodowy stanowi najwyższą formę ochrony przyrody na terenie Polski. Dotychczas utworzono 23 parki narodowe zajmujące zaledwie około 1\% powierzchni państwa ${ }^{1}$.

\footnotetext{
*Adres e-mail: arkadiusz.babczuk@ue.wroc.pl.

** Adres e-mail: marian.kachniarz@ue.wroc.pl.

${ }^{1}$ Ochrona Środowiska 2014, GUS, Warszawa 2014, s. 54.
} 
Walory przyrodnicze i kulturowe polskich parków narodowych powinny być objęte odpowiednimi formami zarządzania. Dopasowane do celu i charakteru działalności regulacje powinny współgrać z rozwojem instytucji nieformalnych, będących sumą mądrości środowisk administracji i ochrony środowiska. Taka definicja uwarunkowań funkcjonowania parków jest związana sferą instytucji formalnych (prawo, zasady finansowe), ale także i nieformalnych (normy zachowań, sposoby postępowania, zdolność do rozwiązywania wspólnych problemów). Instytucje mogą być więc jednocześnie warunkami i ograniczeniami działalności parków, stanowiąc element uwarunkowań zewnętrznych funkcjonowania, jak i kształtowania preferencji i systemów wartości podmiotów.

Celem niniejszego opracowania jest charakterystyka formalnych i nieformalnych ram funkcjonowania parków narodowych w Polsce oraz sformułowanie rekomendacji zmian w tym zakresie. Punktem wyjścia do podjętych badań jest hipoteza, że źle dobrany zestaw norm prawno-finansowych może przeistoczyć się w negatywne bodźce i motywacje działania poszczególnych podmiotów. Bowiem, jak zakładał D. North, procesy gospodarowania nie dokonują się poza prawnym i społecznym kontekstem, dokonują się one w ramach konkretnych instytucji².

Realizacja tego zadania wymagała wieloetapowej procedury. Metoda analizy materiałów źródłowych (desk research) posłużyła do zgromadzenia sprawozdań i planów budżetowych, publikowanych jako załączniki budżetu państwa. W ten sam sposób, z publicznie dostępnych baz aktów prawnych, pozyskano również statuty parków.

Szczegółowość publicznie dostępnych danych finansowych nie pozwoliła, niestety, na realizację tak założonych celów, dlatego w pracy wykorzystano metodę ankietową. Przeprowadzono dwie rundy badań ankietowych, które dotyczyły przede wszystkim szczegółowych grup przychodów i kosztów. Formularze ankiet, przed ich przekazaniem do wypełnienia, były omawiane wcześniej w trakcie indywidualnych spotkań ze wszystkimi głównymi księgowymi 23 parków narodowych.

Metody analityczne, ankietowe oraz rozmowy z głównymi księgowymi parków uzupełniono wywiadami strukturalizowanymi, przeprowadzonymi bezpośrednio z dyrektorami parków. Pozwoliły one na poznanie poglądów wszystkich 23 dyrektorów oraz zorientowanie się w specyficznych, indywidualnych problemach parków.

\footnotetext{
2 D. North, Institutions, Institutional Change and Economic Performance, Cambridge University Press, Cambridge 1994, s. 11-16.
} 


\section{Park narodowy jako jednostka sektora finansów publicznych oraz forma ochrony przyrody}

Polskie Parki Narodowe w ostatnich latach przechodziły kilka fundamentalnych zmian formalnych, które zmieniły podstawy prawne i finansowe ich funkcjonowania. Do końca 2010 roku funkcjonowały jako jednostki budżetowe skarbu państwa z utworzonymi gospodarstwami pomocniczymi, które gromadziły dochody własne jednostki, która tworzyła to gospodarstwo. Istniała zatem zależność stanowiąca podstawę dobrego gospodarowania - dochody stanowiły własność jednostki, która je wypracowywała.

Zmiana ustawy o finansach publicznych i związana z tym likwidacja formuły gospodarstw pomocniczych wymusiły działania dostosowawcze parków narodowych w zakresie ich formy organizacyjnej. Dalsze funkcjonowanie w formie jednostki budżetowej oznaczało, że wszystkie wypracowywane przez park dochody stanowiły dochody budżetu państwa, na którego rachunek musiały być odprowadzane. Minister finansów mógł oczywiście zwracać te środki do miejsca ich wytworzenia w formie dotacji dla jednostki budżetowej. Po pierwsze jednak, nie miał takiego obowiązku, co czyniło to działanie fakultatywnym, a po drugie, wydłużało to znacznie obieg pieniądza. Nieracjonalność tego systemu polegała więc na braku zasady wiążącej dochody z wydatkami, znacznym wydłużeniem czasu między uzyskaniem dochodu a możliwością jego wydatkowania oraz dodatkowych kosztach transferowych. Nie sprzyjało to sprawności zarządzania parkami narodowymi, nic dziwnego zatem, że podjęto starania zmiany formuły prawnej, w jakiej miały one funkcjonować. Wybór padł na tzw. państwową osobę prawną - formę stosunkowo mało rozpowszechnioną w polskim sektorze finansów publicznych.

Państwowe lub samorządowe osoby prawne tworzone są na podstawie odrębnych ustaw w celu wykonywania zadań publicznych ${ }^{3}$. Takim odrębnym przepisem, który konstytuuje formę prawno-finansową parków narodowych, jest ustawa o ochronie przyrody4. Podstawą gospodarki finansowej państwowych osób prawnych jest roczny plan finansowy przekazywany ministrowi finansów. Szczegółowy zakres planów finansowych, obejmujący m.in. przychody z prowadzonej działalno-

\footnotetext{
${ }^{3}$ Art. 8 ust. 1 Ustawy z dnia 27 sierpnia 2009 r. o finansach publicznych (tekst jedn. DzU z 2013 r., poz. 885 z późn. zm.).

${ }^{4}$ Art. 8a ust. 1 Ustawy z dnia 16 kwietnia 2004 r. o ochronie przyrody (tekst jedn. DzU z 2013 r., poz. 627 z późn. zm.).
} 
ści oraz poszczególne kategorie kosztów, określony został w ustawie o finansach publicznych ${ }^{5}$. Oprócz klasycznych planów i sprawozdań finansowych państwowe osoby prawne mają obowiązek sporządzania planów finansowych w układzie zadaniowym na rok budżetowy i dwa kolejne lata.

Powyższe ogólne zasady precyzuje ustawa o ochronie przyrody określająca zadania, które mogą być przez park finansowane. Należą do nich w szczególności ${ }^{6}$ :

- prowadzenie działań ochronnych w ekosystemach parku narodowego,

- udostępnianie obszaru parku narodowego na zasadach określonych w planie ochrony,

- prowadzenie działań związanych z edukacją przyrodniczą.

Analogicznie do katalogu zadań ustawa enumeratywnie wymienia także katalog źródeł przychodów. Należą do nich m.in.?

- dotacje z budżetu państwa,

- wpływy z opłat za wstęp do parku narodowego,

- wpływy ze sprzedaży produktów uzyskiwanych w ramach realizacji zadań wynikających z planu ochrony lub zadań ochronnych (np. sprzedaż drewna),

- środki pochodzące z budżetu Unii Europejskiej.

Ponadto ustawa ta zapewnia samodzielność w zakresie prowadzenia gospodarki finansowej, co oznacza prawo do pokrywania wydatków i kosztów działalności z posiadanych środków i uzyskiwanych przychodów. Prawo to jest z jednej strony ograniczone możliwością finansowania tylko tych wydatków i zadań, które zostały określone w ustawie, a z drugiej - możliwością wprowadzania zmian przychodów i kosztów dopiero po uzyskaniu zgody ministra właściwego do spraw środowiska.

Warto także zwrócić uwagę, że Ustawa o ochronie przyrody przyznaje parkom narodowym prawo wykonywania działalności gospodarczej ${ }^{8}$ na zasadach określonych w Ustawie o swobodzie działalności gospodarczej ${ }^{9}$. Zatem z jednej strony parki narodowe ukonstytuowane zostały jako podmioty gospodarujące, ze swobodą prowadzenia działalności gospodarczej i samodzielnością finansową, z drugiej jednak strony ich sa-

\footnotetext{
${ }^{5}$ Art. 31 Ustawy z dnia 27 sierpnia 2009 r. o finansach publicznych...

${ }^{6}$ Art. 8b ust. 1 Ustawy z dnia 16 kwietnia 2004 r. o ochronie przyrody...

${ }^{7}$ Ibidem, art. 8h, ust. 1.

${ }^{8}$ Ibidem, art. 8b, ust. 2.

${ }^{9}$ Ustawa z dnia 2 lipca 2004 r. o swobodzie działalności gospodarczej (DzU z 2010 r., nr 220, poz. 1447 z późn. zm.).
} 
modzielność została ograniczona jak w typowych jednostkach budżetowych. Typowa państwowa osoba prawna, jako podmiot prowadzący działalność gospodarczą, nie jest obciążona koniecznością uzyskiwania zgody na bieżące zmiany w planie finansowym. Takie ograniczenie jest właściwe dla jednostek budżetowych, które w zasadzie nie prowadzą gospodarki finansowej we własnym imieniu i na własną odpowiedzialność. Można tu zatem dostrzec swoisty dualizm gospodarki finansowej. Jest ona oparta na swobodzie i odpowiedzialności kierowników typowej dla państwowych osób prawnych, jednak z zachowaniem rygorów bieżącego nadzoru finansowo-rzeczowego, właściwych dla jednostek budżetowych (konieczność uzgadniania zmian w planie finansowym).

Warto wskazać także na brak konsekwencji w konstytuowaniu nadzoru nad funkcjonowaniem parków. Plany finansowe parków zatwierdzane są przez ministra właściwego do spraw finansów. Skoro tak, to także zmiany w tym planie powinny należeć do jego kompetencji. Tymczasem, jak już wcześniej wspomniano, regulacja szczegółowa, czyli Ustawa o ochronie przyrody, przekazuje te kompetencje ministrowi właściwemu do spraw środowiska. O dokonanych zmianach minister właściwy do sprawa finansów jest jedynie powiadamiany.

W parkach narodowych nie ma jednolitej polityki rachunkowości (księgowej) ani wzorcowego zakładowego planu kont. Każdy park narodowy, po uzyskaniu statusu państwowej osoby prawnej, kształtował je niezależnie. Szczegółowo prowadzona księgowość i struktura planu kont nie są więc jednolite, co w praktyce uniemożliwia tworzenie spójnej dla wszystkich parków analityki.

Parki narodowe, jako państwowe osoby prawne, powinny prowadzić swoją gospodarkę finansową w układzie memoriałowym (przychodowo-kosztowym), tj. w konwencji quasi-korporacyjnej. Jedynie w zakresie rozliczania się z otrzymanej dotacji z budżetu państwa informacje muszą być przekazywane z uwzględnieniem zasady kasowości. Tymczasem w parkach narodowych, ze względu na wymagania Ministerstwa Środowiska, zarówno plan finansowy, jak i plan finansowy w układzie zadaniowym są sporządzane podwójnie - w układzie memoriałowym i kasowym. Należy jednoznacznie podkreślić, że dla takiej praktyki nie ma jednoznacznej podstawy prawnej.

\section{Analiza i ocena finansowych uwarunkowań funkcjonowania parków narodowych}

Przychody parków narodowych opierają się głównie na przychodach własnych (36\%). Dotacja celowa z budżetu państwa pokrywa jedynie 33\% przychodów. 
Z funduszy europejskich pochodzi 11\% środków. Pozostałe środki (20\%) to głównie dotacje z funduszy krajowych (np. NFOŚiGW, Fundusz Leśny). Struktura przychodów została zaprezentowana na wykresie 1. Dotacje z budżetu są najbardziej stałym źródłem finansowania (choć również zmieniającym się w czasie). Pozostałe przychody mają charakter doraźny i okresowy. Z reguły dotyczą także jasno skonkretyzowanych projektów, a nie działalności bieżącej parku. Struktury przychodów w poszczególnych parkach są bardzo zróżnicowane. Dotacja z budżetu państwa stanowiła w Świętokrzyskim Parku Narodowym 56,2\% przychodów (średnia za lata 2012-2014), podczas gdy w Parku Narodowym Ujście Warty było to tylko 20,3\%.

Wykres 1. Struktura przychodów parków narodowych (2013 r.)
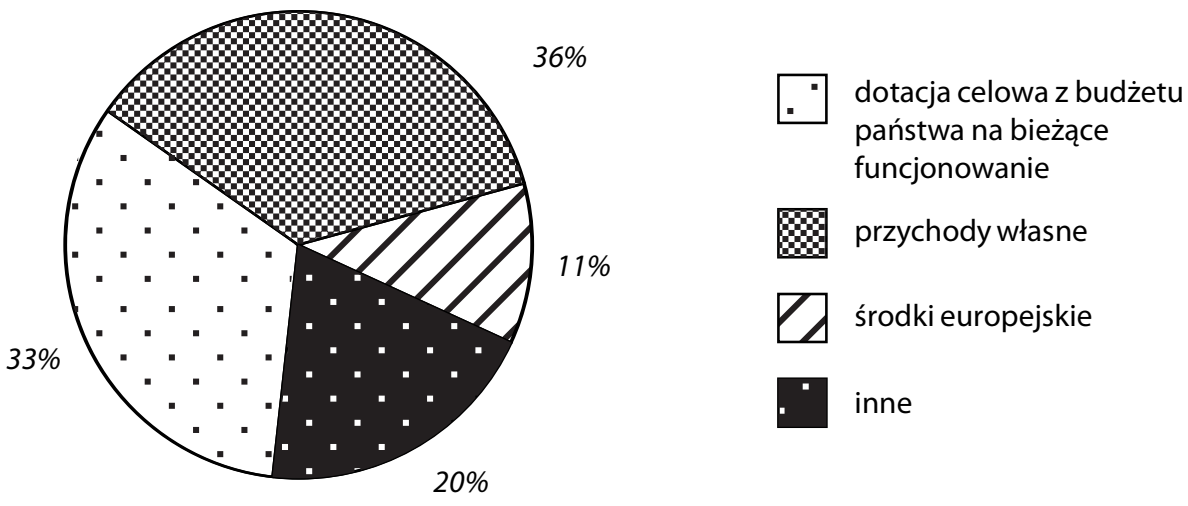

Źródło: opracowanie własne.

Zróżnicowana jest także relacja wielkości dotacji z budżetu państwa do funduszu płac. Mamy tu do czynienia z sytuacją, w której dotacja z budżetu państwa na działania bieżące nie tylko nie pokrywa kosztów bieżących funkcjonowania tych jednostek, ale nawet nie wystarcza na wynagrodzenia. By zbilansować swoją działalność bieżącą, parki muszą pokrywać koszty bieżące przychodami własnymi. Można zatem zauważyć, iż dotujący w sposób jednoznaczny motywuje do aktywnego pozyskiwania innych źródeł przychodów, co może stać w sprzeczności z celami działalności parków narodowych.

W formule państwowej osoby prawnej parki narodowe są podmiotami gospodarującymi, mogącymi osiągać przychody własne. W praktyce najistotniejsze 
kwoty pochodzą ze sprzedaży biletów wstępu do parku i obiektów parkowych, ze sprzedaży drewna pozyskiwanego w ramach działalności ochronnej oraz z dopłat rolno-środowiskowych i dzierżaw terenów nimi objętych. Mniejsze znaczenie mają tu wpływy z działalności edukacyjnej, ze sprzedaży innych produktów związanych z działalnością parku (np. z działalności rybackiej) oraz wpływy z gospodarowania zasobem mieszkaniowym. Widoczna jest ogromna skala zróżnicowania zdolności pozyskiwania przychodów własnych przez poszczególne parki narodowe (wykres 2).

Wykres 2. Przychody własne w przychodach parków ogółem (\%)

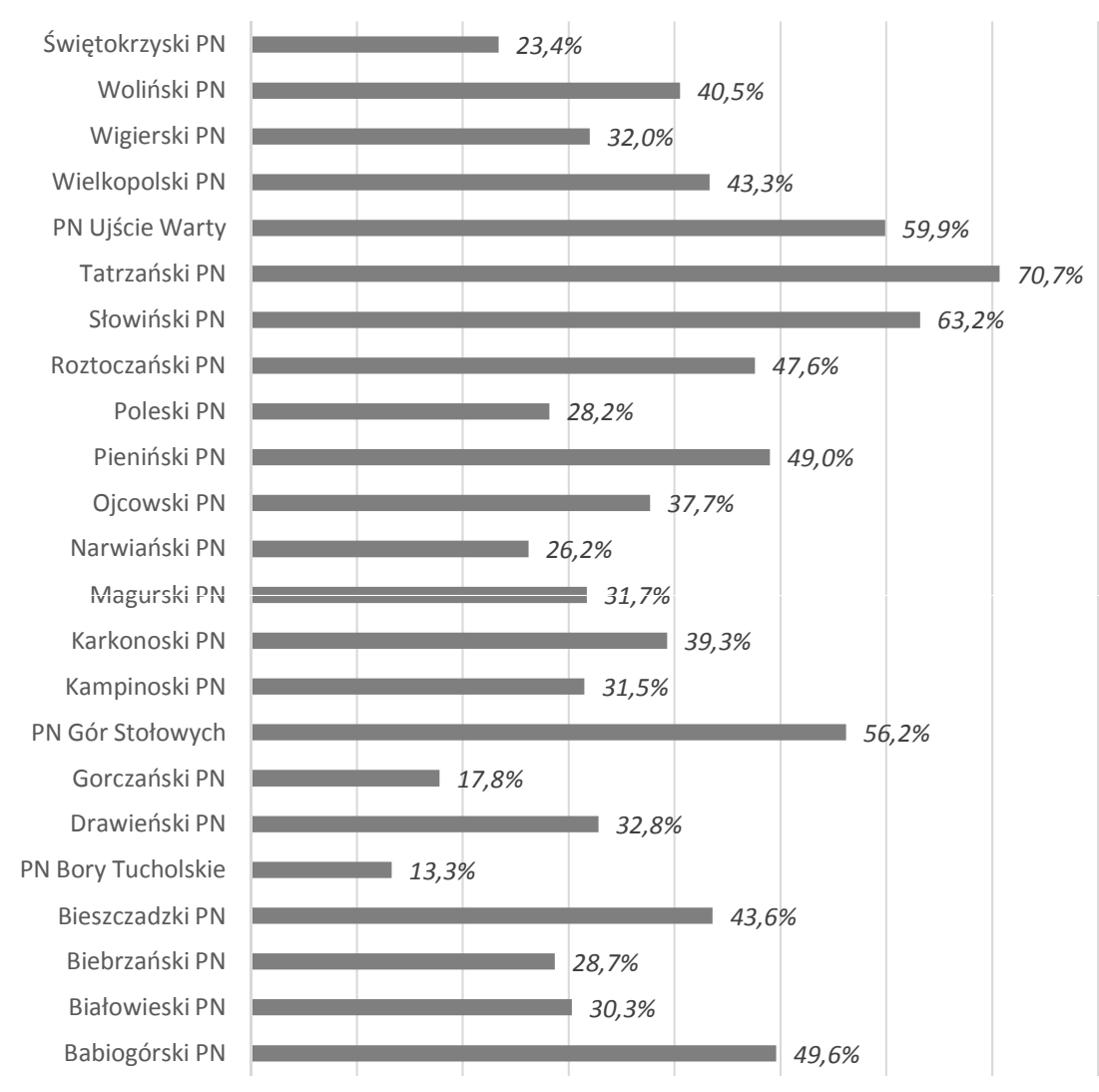

Źródło: opracowanie własne. 
Aktywność w zdobywaniu środków zewnętrznych jest bardzo zróżnicowana (szczegółowo zaprezentowano to na wykresie 3). Na szczególną uwagę zasługują parki wykorzystujące szansę na otrzymywanie środków europejskich, co wymaga szczególnego wysiłku zarówno na etapie przygotowywania projektów, jak i później - w trakcie ich realizacji i rozliczania. Sumarycznie największe kwoty środków europejskich zdobyły: Biebrzański Park Narodowy (ponad 10 mln zł), Karkonoski Park Narodowy (9 mln zł) i Magurski Park Narodowy $(7 \mathrm{mln} z ł)^{10}$.

Wykres 3. Wielkość przychodów parków ze środków UE za lata 2012-2014 (mln zł)

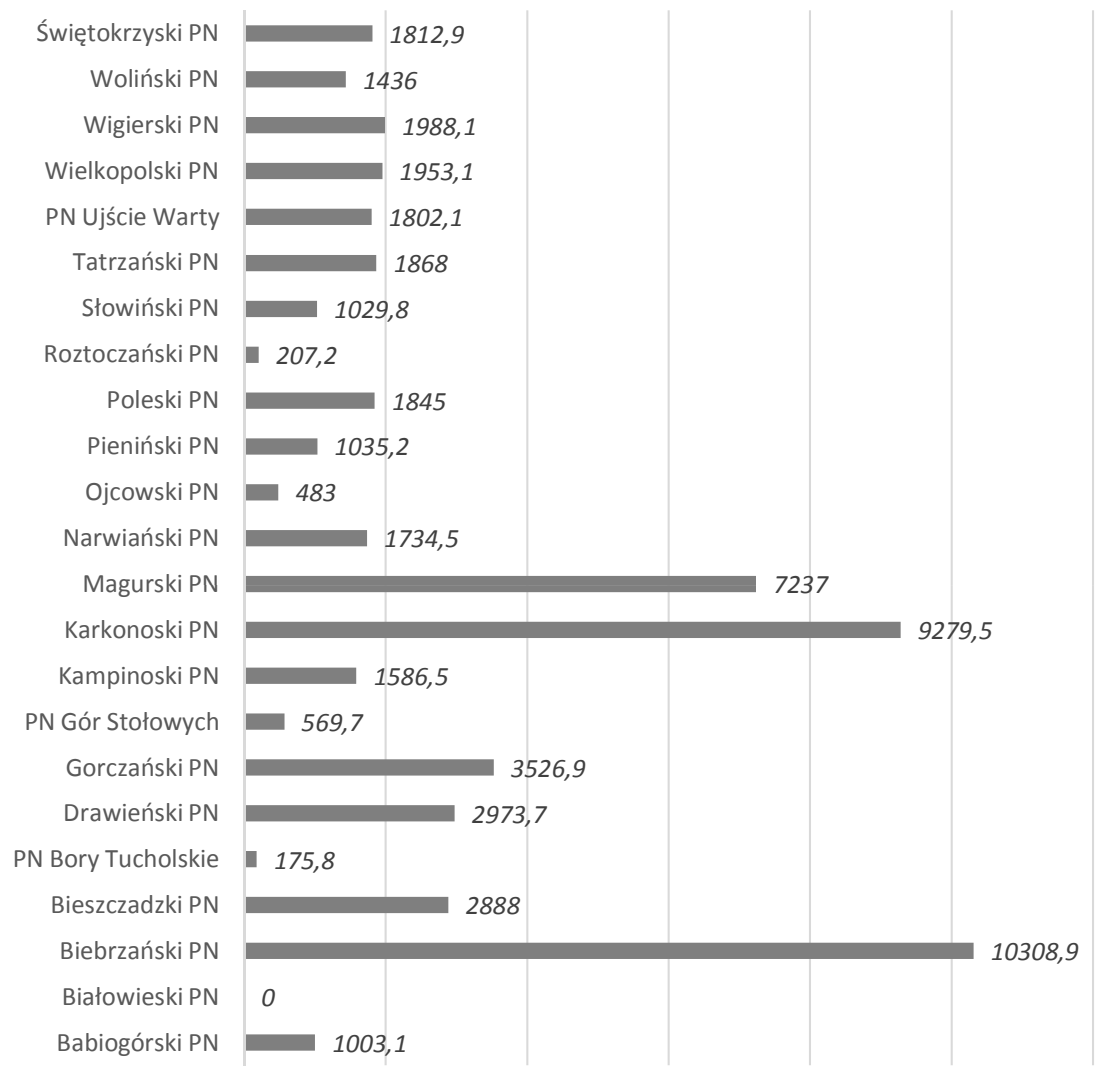

Źródło: opracowanie własne.

\footnotetext{
${ }^{10}$ A. Babczuk, M. Kachniarz, System finansowania parków narodowych w Polsce-stan obecny i kierunki pożądanych zmian, Związek Pracodawców Polskich Parków Narodowych, Jelenia Góra 2015, s. 11.
} 
Relacja dochodów zewnętrznych do dotacji budżetowych może jednak budzić pewne refleksje. W obecnym kształcie bowiem finansowanie parków narodowych oparte jest w mniejszej części na stabilnych i trwałych źródłach dochodu (dotacja budżetowa), przechylając się w sposób znaczący w kierunku źródeł epizodycznych. Przeorientowanie parków na te właśnie źródła może powodować także stopniową ewolucję priorytetów ich działania, z podmiotów chroniących przyrodę w podmioty gospodarujące jej zasobami. Przykładem może być gospodarka leśna. Przebudowa drzewostanów w kierunku optymalnej siedliskowo struktury gatunkowej pozwoli w przyszłości na powiększenie obszarów ochrony biernej. Podobnie utrzymywanie łąk i polan w kulturze rolnej (wykaszanie) pozwoli na zachowanie cennych siedlisk. Problem w tym, że granica między działalnością prośrodowiskową a zdobywaniem $\mathrm{z}$ tego tytułu dochodów ma charakter nieostry.

\section{Podsumowanie}

Regulacje określające funkcjonowanie parków narodowych powinny być wynikiem wspólnych działań środowisk ochrony przyrody i administracji publicznej, opartych na mądrości i doświadczeniu.

Obecne reguły funkcjonowania $\mathrm{z}$ jednej strony zwiększają motywacje i odpowiedzialność dyrektorów, z drugiej - grożą dryftem z pozycji podmiotów chroniących przyrodę w kierunku podmiotów gospodarujących jej zasobami. Pokusa taka rodzi się zwłaszcza z braku jasno określonych reguł finansowania budżetowego. Pojawia się w tym miejscu bardzo poważna groźba zmiany faktycznych priorytetów funkcjonowania parków $-\mathrm{z}$ funkcji ochronnych do funkcji zdobywania przychodów.

Działanie pod ciągłą presją zdobywania przychodów w dłuższym okresie grozi nieformalnymi zmianami reguł ochrony środowiska. $Z$ drugiej strony warto podkreślić, że pomimo formalnych reguł skłaniających dyrektorów do zwiększania przychodów, działają oni według nieformalnych reguł, wynikających z ich głębokiej troski o powierzone im cenne przyrodniczo obszary.

Forma finansowania parków narodowych powinna być adekwatna do charakteru zadań, jakie przed parkami stawiają przepisy Ustawy o ochronie przyrody. Tymczasem zauważamy, że nie ma systemowego sposobu finansowania parków adekwatnego do ich potencjału pozyskiwania przychodów własnych. Jest to jedna 
z nielicznych już sfer sektora finansów publicznych, w których nie zastosowano dotychczas zobiektywizowanych mechanizmów finansowania.

Uznaniowe decyzje przy ograniczonych środkach budżetowych mogą prowadzić do sytuacji, w których większa aktywność dyrektorów w zdobywaniu środków zewnętrznych oraz przychodów własnych może skutkować zmniejszeniem dotacji z budżetu państwa na działalność bieżącą. W ten sposób wzmacnia się demotywacyjny system zarządzania zwiększający skalę trudności tym, którzy wykazują aktywność w zdobywaniu funduszy. Dopasowując się do tych reguł, w dłuższym okresie, dyrektorzy mogą ograniczać swoje zaangażowanie w projekty rozwojowe.

Zatem w świetle przytoczonych wyników badań widać wyraźnie, że pomimo zmian organizacyjnych w praktyce działania parków narodowych funkcjonuje sporo zachowań właściwych jednostkom budżetowym. Jednocześnie odpowiedzialność dyrektorów za powierzone im dziedzictwo opiera się w dużej mierze na regułach nieformalnych. Potrzeba formalizacji tego obszaru jest współistotna z postulatem zmian dysfunkcyjnych regulacji prawno-finansowych, które w przypadku utrwalenia mogą mieć negatywny wpływ na kształtowanie się instytucji nieformalnych.

\section{Literatura}

Babczuk A., Kachniarz M., System finansowania parków narodowych w Polsce - stan obecny i kierunki pożadanych zmian, Związek Pracodawców Polskich Parków Narodowych, Jelenia Góra 2015.

North D., Institutions, Institutional Change and Economic Performance, Cambridge University Press, Cambridge 1994.

Ochrona Środowiska 2014, GUS, Warszawa 2014.

Ustawa z dnia 27 sierpnia 2009 r. o finansach publicznych (tekst jedn. DzU z 2013 r., poz. 885 z późn. zm.).

Ustawa z dnia 16 kwietnia 2004 r. o ochronie przyrody (tekst jedn. DzU 2013 r., poz. 627 z późn. zm.).

Ustawa z dnia 2 lipca 2004 r. o swobodzie działalności gospodarczej (DzU z 2010 r., nr 220, poz. 1447 z późn. zm.). 


\title{
POLISH NATIONAL PARKS - INSTITUTIONAL APPROACH
}

\begin{abstract}
Natural values and cultural Polish national parks should be covered by a special responsibility in the form of appropriate forms of management. The aim of the articleis to characterize the formal and informal framework for the operation of national parks in Poland, and to formulate recommendations for changes in this area. The transformation parks of the state budget entities into the legal state entities gave them greater organizational independence. On the one hand this increases the motivation and responsibility of directors, from the otherside - threatens to drift from position of nature conservation bodies into the direction of corporate entities. From protective functions to the functions of gaining revenue. The temptation engenders especially in the absence of clearly defined rules and limited budgetary financing.

Translated by Marian Kachniarz
\end{abstract}

Keywords: nationalparks, statelegalentities, informalinstitutions

JEL codes: H41, H83, Q57 
